\title{
INSTITUTIONAL QUALITY AND SHADOW ECONOMY: AN INVESTMENT POTENTIAL EVALUATION MODEL
}

\author{
Oleksii Lyulyov and Bogdan Moskalenko
}

\begin{abstract}
The article summarizes some arguments as regards the scientific challenge on improving approaches to evaluating the country's investment potential. The main objective of the research is to identify the features and perspectives of applying the variables such as the shadow economy and the integrated institutional quality index into a model evaluating the country's investment potential. To solve this task, systematization of the related theoretical and methodological materials has been done. The methodological tools of the research are carried out in the following logical sequence: systematization of existing statistical methods for estimating the shadow economy; time data series analysis; and regression analysis. The scope of the shadow economy could be estimated as a dependent variable, with both its determinants and indicators detected and measured. The macro methods, such as Multiple Indicators Multiple Causes (MIMIC) are suitable approaches from an econometric standpoint to evaluate the shadow economy. Institutional quality is crucially an important variable for empirical studies related to evaluating the country's investment potential. The proposed approach considers significance and direction of the six Worldwide Government Indicators' (WGI) impact on foreign direct investment net inflow, eliminating the issue of their multicollinearity. However, political instability and high frequency of foreign and domestic policy changes during the last decades distort statistical significance of the results obtained. FDI inflow, as well as the quality of governance, and the shadow economy, is influenced by many other factors, both internal and external, so to build a qualitative model for evaluating the country's investment potential of the national economy it is necessary to expand the set of factors for analysis. The results of the research can be useful for a more accurate investment potential evaluation on the macroeconomic level, and forecasting foreign direct investment inflows for the following time periods.
\end{abstract}

Keywords: country investment potential, foreign direct investment, shadow economy, national economy, institutional quality

JEL Classification: E22, E29, E44, E60, G31 


\section{Authors:}

Oleksii Lyulyov

Sumy State University, 2 Rimski-Korsakov St., Sumy, Ukraine, 40007

E-mail:alex_lyulev@econ.sumdu.edu.ua

https://orcid.org/0000-0002-4865-7306

\section{Bogdan Moskalenko}

Sumy State University, 2 Rimski-Korsakov St., Sumy, Ukraine, 40007

E-mail: b.mos.sumdu@gmail.com

https://orcid.org/0000-0003-3972-1705

Citation: Lyulyov, O., \& Moskalenko, B. (2020). Institutional Quality and Shadow Economy: An Investment Potential Evaluation Model. Virtual Economics, 3(4), 131-146. https://doi.org/10.34021/ve.2020.03.04(7)

Received: August 26, 2020. Revised: September 15, 2020. Accepted: September 27, 2020.

(C) Author(s) 2020. Licensed under the Creative Commons License - Attribution 4.0 International (CC BY 4.0) 


\section{Introduction}

Foreign direct investment (FDI) has a perceptible impact on local economic development, and is widely considered within related studies as the main driver of host countries' economic growth (Mathur \& Singh, 2013; Ali \& Bohara, 2017; Agnihotri \& Arora, 2019; Huynh et al., 2019). Economic relations are not always conducted within the framework of the bureaucratic public and private sector establishments. In this case, we consider an informal part of economy, so-called shadow, hidden or parallel economy.

Recent publications in this field proposed a wide range of the shadow economy definitions. In this study we use the definition provided by Medina \& Schneider (2018), according to which the shadow economy is explained as all economic activities which are hidden from official authorities due to monetary, regulatory, and institutional reasons.

The informal economy creates various challenges for the whole society as it has a tangible reciprocal relationship among all-important macroeconomic, social, and cultural spheres.

The problem of measuring the informal or shadow economy has been discussed for the last few decades (Lackó, 1996; Lippert \& Walker, 1997; Schneider \& Enste, 2000; Wu \& Schneider, 2019; Dell'Anno et al., 2007; Medina \& Schneider, 2018; Nair-Reichert \& Weinhold, 2001; Pimonenko et al., 2018; Palienko \& Lyulyov, 2018; Elgin, 2019).

Empirical research of current studies which were employed to measuring the size of the shadow economy allows organizing the most common approaches into the related groups, are shown in Table 1.

Table 1. A Taxonomy of Approaches to Measuring the Size of the Shadow Economy

\begin{tabular}{cl}
$\begin{array}{c}\text { Type of } \\
\text { approach }\end{array}$ & \multicolumn{1}{c}{ Definition } \\
\hline Direct & $\begin{array}{l}\text { In this group we include surveys, auditing and other expert methods. Using them, it is possible } \\
\text { to gather detailed information about the structure of shadow economy. It should be } \\
\text { mentioned that the received information may not be representative and may not be } \\
\text { consistent from country to country. }\end{array}$ \\
\hline \multirow{2}{*}{$\begin{array}{l}\text { Indirect } \\
\text { approaches }\end{array}$} & $\begin{array}{l}\text { These methods include the incongruity between income and expenditure measures of GDP; } \\
\text { the difference between official salaries and consumption growth; unemployment dynamic } \\
\text { and average income per capita. Such variables are sensitive to the given assumptions } \\
\text { (elasticity, local currency ratio, base year of comparison, GDP or GNP measurement). }\end{array}$ \\
\hline $\begin{array}{c}\text { A model- } \\
\text { based }\end{array}$ & $\begin{array}{l}\text { The models such as the Multiple Indicator, Multiple Causes (MIMIC) models, proposed by } \\
\text { the size of the shadow economy could be estimated as a dependent variable (an index), with } \\
\text { both its determinants and indicators detected and measured. The obtained equation will be } \\
\text { estimated and the fitted values of the latent variable are used to compute an estimate of the } \\
\text { size of the shadow economy as a share of GDP (Medina \& Schneider, 2018). }\end{array}$ \\
\hline
\end{tabular}

Source: compiled by the authors on the basis of Medina \& Schneider, 2018. 
According to Medina \& Schneider's (2018) estimations, within last 20 years the size of Ukrainian shadow economy was fluctuating within the range of $35-55 \%$, see Figure 1 . It is noticeable that the shadow economy dynamic was highly related to the political situation and the following changes in the government in this period.

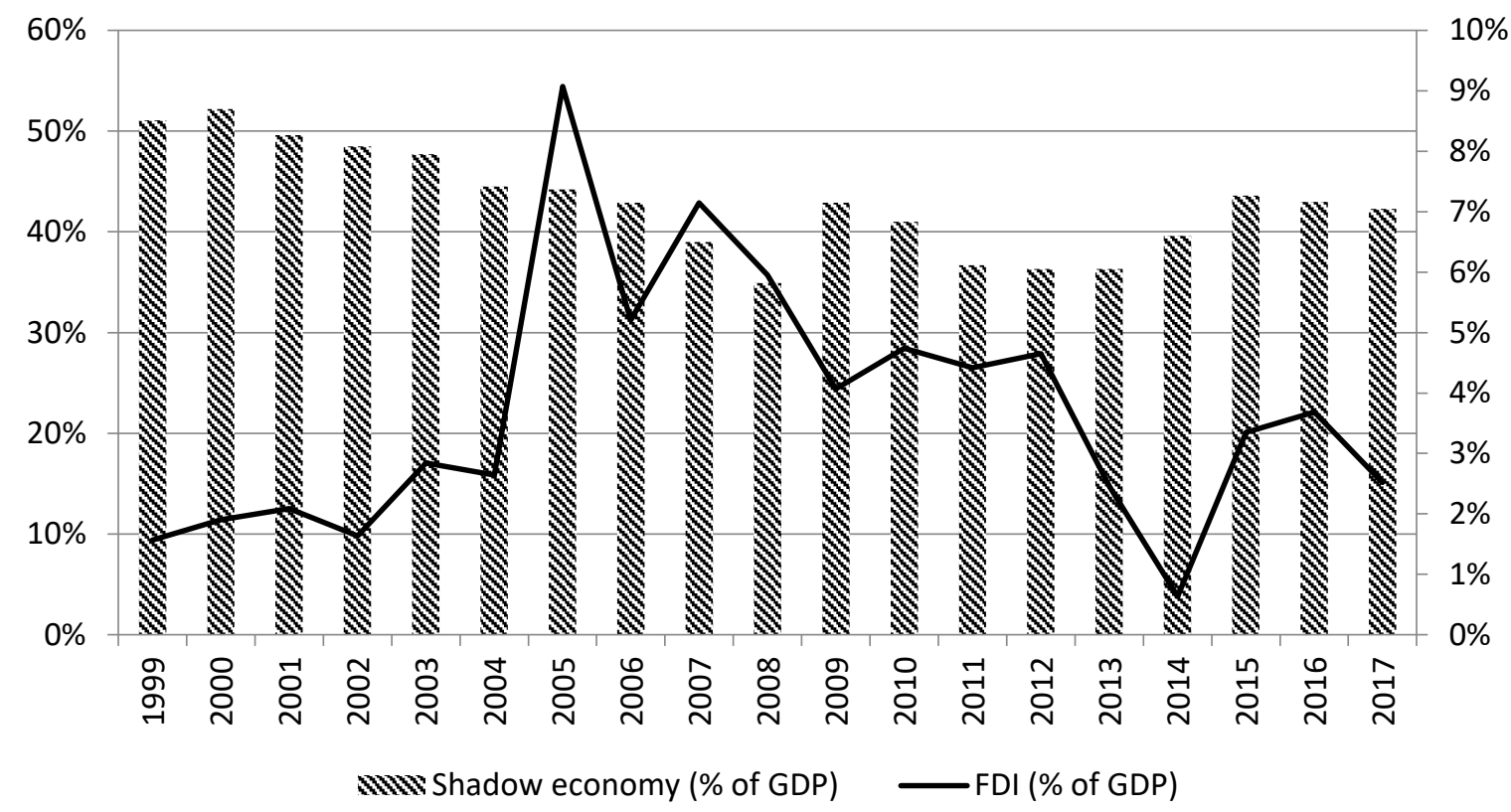

Figure 1. The Shadow Economy (\% of GDP, left axis) and FDI Inflow (\% of GDP, right axis) in Ukraine in the Period of 1999-2017.

Source: World Bank (2018a), Medina \& Schneider (2018).

The early surveys and econometric analyses showed inconclusive results as far as the relation between shadow economy and FDI is concerned.

Substantial research has been carried out on the relation between FDI and institutional environment of a host country economy.

The impact of FDI on the host country economy depends on the quality of the government institutions (Globerman \& Shapiro, 2003; Mathur \& Singh, 2013; Pimonenko \& Lushyk, 2017).

Kaufmann et al. (2011) proposes a Worldwide Governance Indicators Methodology. According to this approach, six main indexes are proposed to estimate the quality of the government institutions which include the following: the process by which the governments are selected, monitored and replaced; the capacity of the government to effectively formulate and implement sound policies; and the respect of citizens and the state for the institutions that govern economic and social interactions among them (World Bank, 2018b). The WGI of Ukraine is shown in Figure 2. 


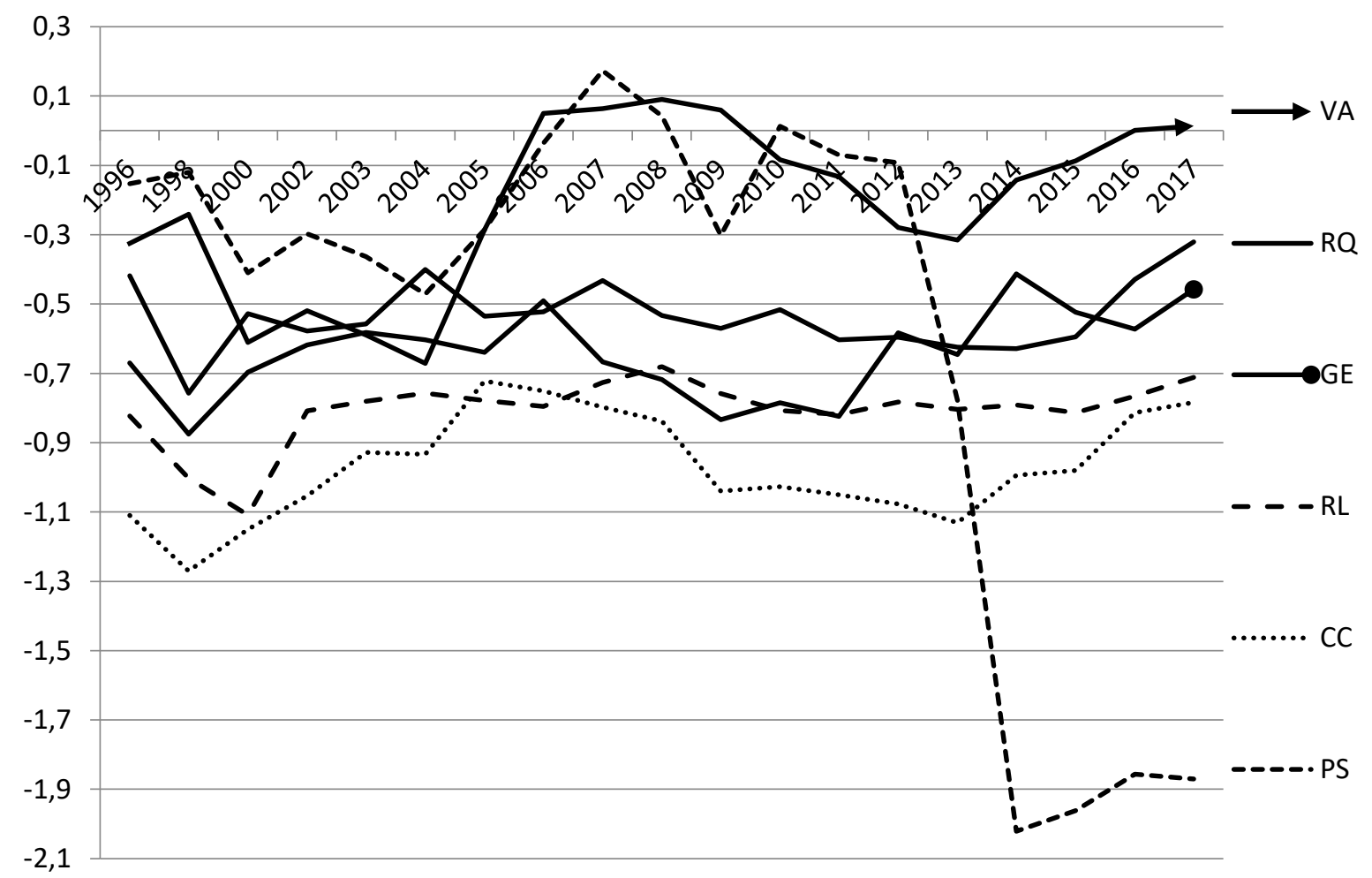

VA -Voice and Accountability, RQ - Regulatory Quality, GE - Government Effectiveness, RL - Rule of Law, CC - Control of Corruption, PS - Political Stability and Absence of Violence

Figure 2. Worldwide Governance Indicators of Ukraine in the Period of 1996-2017. Source: World Bank (2018b).

Figure 2 depicts the fact that the institutional quality did not improve within the analysed period in Ukraine. It is noticeable that political instability, which started in 2013 and largely developed due to upcoming annexation of the Crimea and following military action in the Donbas region, has influenced the country's investment potential and economic activity.

Therefore, it is imperative to comprehensively understand the shadow economy in Ukraine in relation with other variables including FDI inflows and institutional quality.

\section{The Literature Review}

Some questions about the specificity of evaluating the country's investment potential considering the shadow economy and institutional quality were discussed in the papers by (Lackó, 1996; Lippert \& Walker, 1997; Dell'Anno et al., 2007; Schneider et al., 2010; Elgin et al., 2019; Ali \& Bohara, 2017; Prokopenko et al., 2017; Nikopour et al., 2009; Globerman \& Shapiro, 2003; Mathur \& Singh, 2013; Goel et al., 2019; Jöreskog \& Goldberger, 1975). 
Ali \& Bohara (2017) and Nikopour et al. (2009) studied the cross-collinearity between FDI inflows and the size of shadow economy. They resumed that the shadow economy increase could attract FDI.

The presence of shadow economy twists the allocation of resources in the economy, transforms income distribution and reduces tax revenue (Alm \& Embaye, 2013).

Some studies explored a range of the shadow economy effects: government fiscal policy (Cicek \& Elgin, 2011), state employment policy (Schneider \& Enste, 2000), inflation and economic growth (Asfuroglu \& Elgin, 2016), and total factor productivity (D’Erasmo \& Boedo, 2012).

Goel et al. (2019) discussed the influences of FDI inflows, inward development aid, and immigration on the informal sector. They found a positive correlation between FDI inflows and shadow economy.

Discrepancy between national expenditure and income statistics in the process of measuring the shadow economy was explored by Yoo \& Hyun (1998).

Weak institutional quality was found to be a key determinant of the size of shadow economy (Dabla-Norris et al., 2008; Oviedo et al., 2009). They suggested that regulatory burden and weak governance can drive the evolution of the shadow economy.

Some authors (Chen, 1981; Dell'Anno et al., 2007; Posey, 2015) proposed to develop the Multiple Indicators, Multiple Causes (MIMIC) approach based on the statistical theory of unobserved variables developed in the 1970 s by Zellner (1970).

Schneider et al. (2010) further expanded MIMIC approach so it allows to compare the size of shadow economy across countries and to conduct panel data analysis.

It is also necessary to note the applied nature of the work by scientists (Bogachov et al., 2020; Boiko et al., 2019; Czyżewski et al., 2019; Chygryn et al. 2020; Dalevska et al., 2019; Dementyev \& Kwilinski, 2020; Drozdz et al., 2019; 2020; Dzwigol, 2019a; 2019b; 2020a; 2020b; 2020c; Dzwigol \& Wolniak, 2018; Dzwigol \& Dźwigoł-Barosz, 2018; 2020; Dzwigol et al., 2019a; 2019b; 2019c; 2020a; Furmaniak et al., 2018; 2019a; 2019b; Kharazishvili et al., 2020; Kondratenko et al., 2020; Kuzior et al., 2020; Kwilinski, 2017; 2018a; 2018b; 2018c; 2018d; 2019; Kwilinski et al., 2019a; 2019b; 2019c; 2019d; 2019e; 2019f; 2019g; 2020a; 2020b; 2020c; 2020d; Kwilinski \& Kuzior, 2020; Kyrylov et al., 2020; Lakhno et al., 2018; Miskiewicz, 2017a; 2017b; 2018; 2020a; 2020b; Miśkiewicz \& Wolniak, 2020; Pająk et al., 2016; 2017; Prokopenko \& Miśkiewicz, 2020; Saługa et al., 2020; Savchenko et al., 2019; Tkachenko et al., 2019a; 2019b; 2019c; 2019d; 2019e; Yelnikova \& Miskiewicz, 2020), in which special attention is paid to assessing the effectiveness of economic mechanisms' functioning of various scales of activity.

The received results could be applied into other panel data model analyses such as an investment potential evaluation. 


\section{Methods}

Despite abundance of existing approaches to measuring the size of shadow economy, there is no leading or prevailed one, each of them having some conceptual or practical strengths and weaknesses. It is suitable to choose the needed methodology based on the data available, or the research aims. Methods combination might be employed as well, in order to improve preciseness of the estimations. In this study we decided to use the shadow economy estimation results proposed by Medina \& Schneider (2018).

The combination of macroeconomic, microeconomic, and institutional factors which drive the shadow economy could be presumed as the following formula:

$$
S E_{i, t}=\alpha_{i}+\beta X_{i t}+\delta_{t} \text { Time }_{t}+u_{i, t}
$$

where $\mathrm{SE}_{\mathrm{i}, \mathrm{t}}$ represents the size of the shadow economy in the country $i$ at a time period $t$ as a share of GDP;

$\alpha_{i}$ are the country's fixed effects;

$X_{i t}$ is a vector of macroeconomic variables and institutional indicators;

Time $_{t}$ are time fixed effects, which are included to control unexpected year-related variation and special events;

$u_{i, t}$ is the error term;

$\beta, \delta$ are individual specific effects.

Worldwide Governance Indicators methodology calculates six indexes which represent the quality of governance, as it is shown in Figure 2. Some of them are correlated with each other. Thus, Bilan et al. (2019) proposed the approach to integrate WGI index based on the Fishburne's method, considering the impact's power and direction of the different subindexes WGI on FDI inflow and eliminating the issue of multicollinearity. To calculate, it is suggested to use the formula:

$$
W G I=\sum_{i=1}^{n} w_{i} \times W G I_{i}=\sum_{i=1}^{n} \frac{2(n-j+1)}{n(n+1)} \times W G I_{i, t},
$$

where $w_{i}$ is the weight of $i$ sub-index;

$n$ is the quantity of sub-indexes;

$j$ is a rank of sub-index;

$W G I_{i, t}$ are the calculated $i$ sub-index values.

The calculated independent variables (integrated WGI, and the shadow economy rate) are supposed to be applied into an investment potential evaluation model. The general model is presumed by the formula: 


$$
F D I_{i, t}=\alpha_{0}+\alpha_{1} F D I_{i, t-1}+\alpha_{2} X_{i, t}+\alpha_{3} W G I_{i, t}+\alpha_{4} S E_{i, t}+\varepsilon_{i t}
$$

where $F D I_{i, t}$ is the FDI net inflow in country $i$ at a time period $t$ as a share of GDP; $\alpha_{0}-\alpha_{4}$ are individual specific effects.

Some of statistical data ought to be represented as their logarithmic interpretation in order to achieve a visual effect needed. The data processing was done via STATA 14.

\section{Results and Discussion}

As explained in the previous section, the MIMIC model assumes specific effects and determinants that are used to measure the size of the shadow economy. Table 2 shows the regression results for the models from Equations (1) - (3). Empirical results of the shadow economy influence on FDI are provided in the studies by Medina \& Schneider (2018). The source of calculating integrated WGI index is the World Bank (2018b).

Table 2. The Regression Analysis of the Shadow Economy and the Quality of Governance Impact on FDI Net Inflows.

\begin{tabular}{|c|c|c|c|c|c|c|}
\hline \multirow{2}{*}{ Source } & \multirow{2}{*}{ SS } & \multirow{2}{*}{$d f$} & \multirow{2}{*}{ MS } & \multirow{2}{*}{$\begin{array}{l}\text { Number of obs } \\
F(1,18)\end{array}$} & \multirow{2}{*}{$\begin{array}{l}= \\
=\end{array}$} & \multirow{2}{*}{$\begin{array}{l}19 \\
29.04\end{array}$} \\
\hline & & & & & & \\
\hline Model & 2.86323374 & 1 & 1.43161687 & Prob $>F$ & $=$ & 0.0000 \\
\hline Residual & 0.788767185 & 16 & 0.049297949 & R-squared & $=$ & 0.7840 \\
\hline \multirow{2}{*}{ Total } & \multirow{2}{*}{3.65200092} & \multirow{2}{*}{18} & & Adj R-squared & $=$ & 0.7570 \\
\hline & & & & Root MSE & $=$ & 0.22203 \\
\hline InFDI & Coef. & Std. Err. & $\mathrm{t}$ & $P>|t|$ & Conf. & Interval] \\
\hline SE & -0.0731997 & 0.0129622 & -5.65 & 0.000 & 6784 & -0.0457211 \\
\hline WGI & 1.26816 & 0.4443008 & 2.85 & 0.011 & 2838 & 2.210035 \\
\hline cons & 11.39487 & 0.5331893 & 25.12 & 0.000 & 456 & 14.52518 \\
\hline
\end{tabular}

Sources: developed by the authors.

The analysis results showed that the impact of the shadow economy and the institutional quality on FDI inflow is considerable, and could be applied on the country investment evaluation model, see Table 2.

The regression analysis has shown that $R^{2}=0.78$, which means a significant impact of the shadow economy rate and institution quality on FDI net inflows, although $P$-value $(P>|t|)$ is less than 0.05 , which indicates a high level of statistical significance of the whole model.

Following the results shown in Table 2, the change in FDI inflow can be characterized by a regression model: 


$$
Y=11.39487+1.26816 W G I-0.0731997 S E
$$

where $Y$ is $\ln$ (FDI net inflows, USD);

WGI is an integrated WGI index based on the Fishburne's method;

$S E$ is the shadow economy rate (\% of GDP).

The main result obtained from the regression model shows that one unit increase in shadow economy rate (\% of GDP) decreases FDI inflows by 0.073 (at logarithmic scale). At the same time, the quality of governance has a positive and significant impact on FDI inflow. This means that multinational companies look for opportunities to evade taxes when making investment decisions, but consider investing in the countries with a reasonably good governance infrastructure.

It should be noted that the dynamics of FDI inflow, as well as the quality of governance, and the shadow economy, are influenced by many other factors, both internal and external, so to build a qualitative model evaluating a country's investment potential of the national economy it is necessary to expand the set of factors for analysis. The concluding section follows.

\section{Conclusions}

Adding to the literature on the investment potential evaluation approaches, this paper studies the problems and prospective of applying independent variables such as the size of shadow economy and an integrated index of institutional quality.

The obtained results show that the shadow economy rate, calculated by MIMIC methodology, is suitable for applying into an investment potential evaluation model. It should be noticed that the shadow economy itself could be measured by FDI as an indicator.

An institutional quality creates the environment for economic activity in a country. Thus, evaluation of this variable is crucially important for each related empirical study. At the same time, a relatively high frequency of foreign and domestic policy changes during the last decades distorts the statistical significance of the obtained results.

Nevertheless, there is still significant room for improving as well as for expanding the evaluation approach discussed in the current study. First, the used dataset can be further expanded provided the data are available for several countries. Second, the empirical analysis, which is conducted after the evaluation, should be deepened, with more data series applied.

\section{Formatting of Funding Sources}

This research received no external funding. 


\section{References}

Agnihotri, An., \& Arora, Sh. (2019). Study of Linkages between Outward Foreign Direct Investment (OFDI) and Domestic Economic Growth: an Indian Perspective. Financial Markets, Institutions and Risks, 3(1), 43-49.

Ali, M., \& Bohara, A. K. (2017). How Does FDI Respond to the Size of Shadow Economy: An Empirical Analysis under a Gravity Model Setting? International Economic Journal, 31(2), 159178. https://doi.org/10.1080/10168737.2017.1314533.

Alm, J., \& Embaye, A. (2013). Using Dynamic Panel Methods to Estimate Shadow Economies around the World, 1984-2006. Public Finance Review, 41(5), 510-543.

Asfuroglu, D., \& Elgin C. (2016). Growth Effects of Inflation under the Presence of Informality. Bulletin of Economic Research, 68(4), 311-328

Bilan, Y., Raišienè, A., Vasilyeva, T., Lyulyov, O., \& Pimonenko, T. (2019). Public Governance Efficiency and Macroeconomic Stability: Examining Convergence of Social and Political Determinants. Public Policy and Administration, 18(2), 241-255. https://doi.org/10.13165/vpa-19-18-2-05.

Bogachov, S., Kwilinski, A., Miethlich, B., Bartosova, V., Gurnak, A. (2020). Artificial Intelligence Components and Fuzzy Regulators in Entrepreneurship Development. Entrepreneurship and Sustainability Issues, 8(2), 487-499. http://doi.org/10.9770/jesi.2020.8.2(29)

Boiko, V., Kwilinski, A., Misiuk, M., \& Boiko, L. (2019). Competitive Advantages of Wholesale Markets of Agricultural Products as a Type of Entrepreneurial Activity: The Experience of Ukraine and Poland. Economic Annals-XXI, 175(1-2), 68-72. https://doi.org/10.21003/ea.V175-12

Chen C. (1981). The EM Approach to the Multiple Indicators and Multiple Causes Model via the Estimation of the Latent Variable. Journal of American Statistical Association, 76, 704-708.

Chygryn, O., Bilan, Y., \& Kwilinski, A. (2020). Stakeholders of Green Competitiveness: Innovative Approaches for Creating Communicative System. Marketing and Management of Innovations, 3, 356-368. https://doi.org/10.21272/mmi.2020.3-26

Cicek, D., \& Elgin, C. (2011). Cyclicality of Fiscal Policy and the Shadow Economy. Empirical Economics, 413, 725-737.

Czyżewski, B., Matuszczak, A., \& Miskiewicz, R. (2019). Public Goods Versus the Farm Price-Cost Squeeze: Shaping the Sustainability of the EU's Common Agricultural Policy. Technological and Economic Development of Economy, 25(1), 82-102. https://doi.org/10.3846/tede.2019.7449

D’Erasmo, P., \& Boedo, H. (2012). Financial Structure, Informality and Development. Journal of Monetary Economics, 59(3), 286-302.

Dabla-Norris, E., Gradstein, M., \& Inchauste, G. (2008). What Causes Firms to Hide Output? The Determinants of Informality. Journal of Development Economics, 85(1), 1-27

Dalevska, N., Khobta, V., Kwilinski, A., \& Kravchenko, S. (2019). A Model for Estimating Social and Economic Indicators of Sustainable Development. Entrepreneurship and Sustainability Issues, 6(4), 1839-1860. https://doi.org/10.9770/jesi.2019.6.4(21)

Dell'Anno, R., Gómez, M., \& Pardo, A. (2007). The Shadow Economy in Three Mediterranean Countries: France, Spain and Greece. A MIMIC Approach. Empirical Economics, 33(1), 51-84. https://doi.org/10.1007/s00181-006-0084-3. 
Dementyev, V.V., \& Kwilinski, A. (2020). Institutsionalnaya sostavlyayuschaya izderzhek proizvodstva [Institutional Component of Production Costs]. Journal of Institutional Studies, 12(1), 100-116. https://doi.org/10.17835/2076-6297.2020.12.1.100-116

Drozdz, W., Miskiewicz, R., Pokrzywniak, J., \& Elzanowski, F. (2019). Urban Electromobility in the Context of Industry 4.0. Torun: Wydawnictwo Adam Marszalek.

Drozdz, W., Marszalek-Kawa, J., Miskiewicz, R., \& Szczepanska-Waszczyna, K. (2020). Digital Economy in the Contemporary World. Torun: Wydawnictwo Adam Marszalek.

Dzwigol, H. (2019a). The Concept of the System Approach of the Enterprise Restructuring Process. Virtual Economics, 2(4), 46-70. https://doi.org/10.34021/ve.2019.02.04(3)

Dzwigol, H. (2019b). Research Methods and Techniques in New Management Trends: Research Results. Virtual Economics, 2(1), 31-48. https://doi.org/10.34021/ve.2019.02.01(2)

Dzwigol, H. (2020a). Innovation in Marketing Research: Quantitative and Qualitative Analysis. Marketing and Management of Innovations, 1, 128-135. http://doi.org/10.21272/mmi.2020.1-10

Dzwigol, H. (2020b). Methodological and Empirical Platform of Triangulation in Strategic Management. Academy of Strategic Management Journal, 19(4), 1-8.

Dźwigoł, H. (2020c). Interim Management as a New Approach to the Company Management. Review of Business and Economics Studies, 8(1), 20-26. https://doi.org/10.26794/2308-944X-2020-8-1-2026

Dzwigol, H., \& Wolniak, R. (2018). Controlling w procesie zarządzania chemicznym przedsiębiorstwem produkcyjnym [Controlling in the Management Process of a Chemical Industry Production Company]. Przemys/ Chemiczny, 97(7), 1114-1116. https://doi.org/10.15199/62.2018.7.15

Dzwigol, H., \& Dźwigoł-Barosz, M. (2018). Scientific Research Methodology in Management Sciences. Financial and Credit Activity: Problems of Theory and Practice, 2(25), 424-437. https://doi.org/10.18371/fcaptp.v2i25.136508

Dzwigol, H., \& Dzwigol-Barosz, M. (2020). Sustainable Development of the Company on the Basis of Expert Assessment of the Investment Strategy. Academy of Strategic Management Journal, 19(5), 1-7.

Dzwigol, H., Shcherbak, S., Semikina, M., Vinichenko, O., \& Vasiuta, V. (2019a). Formation of Strategic Change Management System at an Enterprise. Academy of Strategic Management Journal, 18(SI1), 1-8.

Dzwigol, H., Aleinikova, O., Umanska, Y., Shmygol, N., \& Pushak, Y. (2019b). An Entrepreneurship Model for Assessing the Investment Attractiveness of Regions. Journal of Entrepreneurship Education, 22(1S), 1-7.

Dzwigoł, H., Dzwigoł-Barosz, M., Zhyvko, Z., Miskiewicz, R., \& Pushak, H. (2019c). Evaluation of the Energy Security as a Component of National Security of the Country. Journal of Security and Sustainability Issues, 8(3), 307-317. http://doi.org/10.9770/jssi.2019.8.3(2)

Dzwigol, H., Dźwigoł-Barosz, M., \& Kwilinski, A. (2020d). Formation of Global Competitive Enterprise Environment Based on Industry 4.0 Concept. International Journal of Entrepreneurship, 24(1), 1-5.

Dzwigol, H., Dzwigol-Barosz, M., Miskiewicz, R., \& Kwilinski, A. (2020). Manager Competency Assessment Model in the Conditions of Industry 4.0. Entrepreneurship and Sustainability Issues, 7(4), 2630-2644. https://doi.org/10.9770/jesi.2020.7.4(5) 
Elgin, C. (2019). Shadow Economies Around the World: Evidence from Metropolitan Areas. Eastern Economic Journal. https://doi.org/10.1057/s41302-019-00161-4

Frey, B.S., \& Weck-Hanneman, H. (1984). The Hidden Economy as an 'Unobserved' Variable. European Economic Review, 26(1-2), 33-53. https://doi.org/10.1016/0014-2921(84)90020-5.

Furmaniak, S., Gauden, P.A., Patrykiejew, A., Miśkiewicz, R., \& Kowalczyk, P. (2018). Carbon Nanohorns as Reaction Nanochambers - a Systematic Monte Carlo Study. Scientific Reports, 15407. https://doi.org/10.1038/s41598-018-33725-z

Furmaniak, S., Gauden, P.A., Patrykiejew, A., Miskiewicz, R., \& Kowalczyk, P. (2019a). The Effects of Confinement in Pores Built of Folded Graphene Sheets on the Equilibrium of Nitrogen Monoxide Dimerisation Reaction. Journal of Physics Condensed Matter, 31(13), 135001, 1-12. https://doi.org/10.1088/1361-648X/aaffb3

Furmaniak, S., Gauden, P.A., Patrykiejew, A., Szymański, G., Miśkiewicz, R., \& Kowalczyk, P. (2019b). In Silico Study on the Effects of Carbonyl Groups on Chemical Equilibrium of Reactions with a Polar Product Occurring under Confinement in Pores of Activated Carbons. Chemical Engineering Communications, 1-12. https://doi.org/10.1080/00986445.2019.1700115

Globerman, S., \& Shapiro, D. (2003). Global Foreign Direct Investment Flows: The Role of Governance Infrastructure. World Development, 30, 1899-1919.

Goel, R. K., Ram, R., Schneider, F., \& Potempa, A. (2019). International Movements of Money and Men: Impact on the Informal Economy. Journal of Economics and Finance, 44, 179197. https://doi.org/10.1007/s12197-019-09480-w.

Huynh, C. M., Nguyen, V. H. T., Nguyen, H. B., \& Nguyen, P. C. (2019). One-Way Effect or Multiple-Way Causality: Foreign Direct Investment, Institutional Quality and Shadow Economy? International Economics and Economic Policy, 17, 219-239. https://doi.org/10.1007/s10368-019-00454-1.

Jöreskog, K. G., \& Goldberger, A. S. (1975). Estimation of a Model with Multiple Indicators and Multiple Causes of a Single Latent Variable. Journal of the American Statistical Association, 70(351a), 631639. https://doi.org/10.1080/01621459.1975.10482485

Kaufmann, D., Kraay, A., \& Mastruzzi, M. (2011). The Worldwide Governance Indicators: Methodology and Analytical Issues. Hague Journal on the Rule of Law, 3(02), 220-246.

Kondratenko, V., Okopnyk, O., Ziganto, L., \& Kwilinski, A. (2020). Innovation Development of Public Administration: Management and Legislation Features. Marketing and Management of Innovations, 1, 87-94. https://doi.org/10.21272/mmi.2020.1-06

Kharazishvili, Y., Kwilinski, A., Grishnova, O., \& Dzwigol, H. (2020). Social Safety of Society for Developing Countries to Meet Sustainable Development Standards: Indicators, Level, Strategic Benchmarks (with Calculations Based on the Case Study of Ukraine). Sustainability, 12(21), 8953. https://doi.org/10.3390/su12218953

Kuzior, A., Kwilinski, A., \& Tkachenko, V. (2019). Sustainable Development of Organizations Based on the Combinatorial Model of Artificial Intelligence. Entrepreneurship and Sustainability, 7(2), 13531376. http://doi.org/10.9770/jesi.2019.7.2(39)

Kwilinski, A. (2017). Development of Industrial Enterprise in the Conditions of Formation of Information Economics. Thai Science Review, Autumn 2017, 85-90. https://doi.org/10.5281/zenodo.1414236

Kwilinski, A. (2018a). Mechanism of Formation of Industrial Enterprise Development Strategy in the Information Economy. Virtual Economics, 1(1), 7-25. https://doi.org/10.34021/ve.2018.01.01(1) 
Kwilinski, A. (2018b). Mechanism of Modernization of Industrial Sphere of Industrial Enterprise in Accordance with Requirements of the Information Economy. Marketing and Management of Innovations, 4, 116-128. http://doi.org/10.21272/mmi.2018.4-11

Kwilinski, A. (2018c). Mechanism for Assessing the Competitiveness of an Industrial Enterprise in the Information Economy. Research Papers in Economics and Finance, 3(1), 7-16. https://doi.org/10.18559/ref.2018.1.1

Kwilinski, A. (2018d). Trends of Development of the Information Economy of Ukraine in the Context of Ensuring the Communicative Component of Industrial Enterprises. Economics and Management, 1(77), 64-70.

Kwilinski, A. (2019). Implementation of Blockchain Technology in Accounting Sphere. Academy of Accounting and Financial Studies Journal, 23(SI2), 1-6.

Kwilinski, A., Tkachenko, V., \& Kuzior, A. (2019a). Transparent Cognitive Technologies to Ensure Sustainable Society Development. Journal of Security and Sustainability Issues, 9(2), 561-570 http://doi.org/10.9770/jssi.2019.9.2(15)

Kwilinski, A., Drobyazko, S., \& Derevyanko, B. (2019b). Synergetic and Value Effects in Corporate Mergers and Acquisitions of International Companies. In Khalid S. Soliman (Ed.), Proceedings of the 34th International Business Information Management Association Conference (IBIMA) 13-14 November 2019. Vision 2025: Education Excellence and Management of Innovations through Sustainable Economic Competitive Advantage in 2019 (pp. 9467-9471). Madrid, Spain: IBIMA Publishing.

Kwilinski, A., Dalevska, N., Kravchenko, S., Hroznyi, I., Kovalenko, I. (2019c). Formation of the Entrepreneurship Model of E-Business in the Context of the Introduction of Information and Communication Technologies. Journal of Entrepreneurship Education, 22(SI1), 1528-2651-22-S1337: 1-7.

Kwilinski, A., Ruzhytskyi, I., Patlachuk, V., Patlachuk, O., \& Kaminska, B. (2019d). Environmental Taxes as a Condition of Business Responsibility in the Conditions of Sustainable Development. Journal of Legal, Ethical and Regulatory Issues, 22(SI2) 1544-0044-22-SI-2-354: 1-6.

Kwilinski, A., Volynets, R., Berdnik, I., Holovko, M., \& Berzin, P. (2019e). E-Commerce: Concept and Legal Regulation in Modern Economic Conditions. Journal of Legal, Ethical and Regulatory Issues, 22(SI2), 1544-0044-22-SI-2-357: 1-6.

Kwilinski, A., Dzwigol, H., \& Dementyev, V. (2019f). Transnational Corporations as Entities of International Entrepreneurship. International Journal of Entrepreneurship, 23(SI4), 1-6.

Kwilinski, A., Pajak, K., Halachenko, O., Vasylchak, S., Pushak, Ya., \& Kuzior, P. (2019g). Marketing Tools for Improving Enterprise Performance in the Context of Social and Economic Security of the State: Innovative Approaches to Assessment. Marketing and Management of Innovations, 4, 172-181. http://doi.org/10.21272/mmi.2019.4-14

Kwilinski, A., \& Kuzior, A. (2020). Cognitive Technologies in the Management and Formation of Directions of the Priority Development of Industrial Enterprises. Management Systems in Production Engineering, 28(2), 119-123. http://doi.org/10.1515/mspe-2019-0020

Kwilinski, A., Vyshnevskyi, O., \& Dzwigol, H. (2020a). Digitalization of the EU Economies and People at Risk of Poverty or Social Exclusion. Journal of Risk and Financial Management, 13(7), 142. https://doi.org/10.3390/jrfm13070142 
Kwilinski, A., Zaloznova, Y., Trushkina, N., \& Rynkevych, N. (2020b). Organizational and Methodological Support for Ukrainian Coal Enterprises Marketing Activity Improvement. E3S Web of Conferences, 168, 00031. https://doi.org/10.1051/e3sconf/202016800031

Kwilinski, A., Dielini, M., Mazuryk, O., Filippov, V., \& Kitseliuk, V. (2020c). System Constructs for the Investment Security of a Country. Journal of Security and Sustainability Issues, 10(1), 345-358. https://doi.org/10.9770/jssi.2020.10.1(25)

Kwilinski, A., Shteingauz, D., \& Maslov, V. (2020). Financial and Credit Instruments for Ensuring Effective Functioning of the Residential Real Estate Market. Financial and Credit Activities: Problems of Theory and Practice, 3(34), 133-140. Retrieved from https://fkd.ubs.edu.ua/index.php/fkd/article/view/3023

Kyrylov, Y., Hranovska, V., Boiko, V., Kwilinski, A., \& Boiko, L. (2020). International Tourism Development in the Context of Increasing Globalization Risks: On the Example of Ukraine's Integration into the Global Tourism Industry. Journal of Risk and Financial Management, 13(12), 303. https://doi.org/10.3390/jrfm13120303

Lackó, M. (1996). Hidden economy in East-European countries in international comparison. Luxenburg: International Institute for Applied Systems Analysis (IIASA).

Lakhno, V., Malyukov, V., Bochulia, T., Hipters, Z., Kwilinski, A., \& Tomashevska, O. (2018). Model of Managing of the Procedure of Mutual Financial Investing in Information Technologies and Smart City Systems. International Journal of Civil Engineering and Technology, 9(8), 1802-1812.

Lippert, O., \& Walker, M. (Eds.). (1997). The Underground Economy: Global Evidences of its Size and Impact. Vancouver, B.C.: The Frazer Institute.

Mathur, A., \& Singh, K. (2013). Foreign Direct Investment, Corruption and Democracy. Applied Economics, 45(8), 991-1002.

Medina, L., \& Schneider, F. (2018). Shadow Economies Around the World: What Did We Learn Over the Last 20 Years? IMF Working Papers, 18/17, 1-76. Retrieved from https://www.imf.org/en/Publications/WP/Issues/2018/01/25/Shadow-Economies-Around-theWorld-What-Did-We-Learn-Over-the-Last-20-Years-45583.

Miskiewicz, R. (2017a). Knowledge in the Process of Enterprise Acquisition. Progress in Economic Sciences, 4, 415-432. https://doi.org/10.14595/PES/04/029

Miskiewicz, R. (2017b). Knowledge Transfer in Merger and Acquisition Processes in the Metallurgical Industry. Warsaw: PWN.

Miskiewicz, R. (2018). The Importance of Knowledge Transfer on the Energy Market. Polityka Energetyczna, 21(2), 49-62. http://dx.doi.org/10.24425\%2F122774

Miskiewicz, R. (2019). Challenges Facing Management Practice in the Light of Industry 4.0: The Example of Poland. Virtual Economics, 2(2), 37-47. https://doi.org/10.34021/ve.2019.02.02(2)

Miskiewicz, R. (2020). Internet of Things in Marketing: Bibliometric Analysis. Marketing and Management of Innovations, 3, 371-381. http://doi.org/10.21272/mmi.2020.3-27

Miskiewicz, R. (2020a). Efficiency of Electricity Production Technology from Post-Process Gas Heat: Ecological, Economic and Social Benefits. Energies, 13(22), 6106. https://doi.org/10.3390/en13226106 
Miśkiewicz, R, \& Wolniak, R. (2020b). Practical Application of the Industry 4.0 Concept in a Steel Company. Sustainability, 12(14), 5776. https://doi.org/10.3390/su12145776

Nair-Reichert, U., \& Weinhold, D. (2001). Causality Tests for Cross-Country Panels: A New Look at FDI and Economic Growth in Developing Countries. Oxf Bull Econ Stat, 63(2), 153-171.

Nikopour, H., Habibullah, M., Schneider, F., \& Law, S. (2009) Foreign Direct Investment and Shadow Economy: A Causality Analysis Using Panel Data. MPRA paper, 14485.

Oviedo, A. M., Thomas, M. R., \& Karakurum-Ozdemir, K. (2009). Economic Informality: Causes, Costs, and Policies - A Literature Survey. World Bank Working Paper, no. 167. Washington, D.C.: World Bank. Retrieved from https://openknowledge.worldbank.org/handle/10986/5917

Palienko, M., \& Lyulyov, O. (2018). The Impact of Social Factors on Macroeconomic Stability: Empirical Evidence for Ukraine and European Union Countries. SocioEconomic Challenges, 2(1), 103-116.

Pająk, K., Kamińska, B., \& Kvilinskyi, O. (2016). Modern Trends of Financial Sector Development under the Virtual Regionalization Conditions. Financial and Credit Activity: Problems of Theory and Practice, 2(21), 204-217. https://doi.org/10.18371/fcaptp.v2i21.91052

Pająk, K., Kvilinskyi, O., Fasiecka, O., \& Miskiewicz, R. (2017). Energy Security in Regional Policy in Wielkopolska Region of Poland. Economics and Environment, 2(61), 122-138.

Pimonenko, T., \& Lushyk, K. (2017). Zelene investuvannya: dosvid EU dlia Ukrayiny [Green Investing: The EU Experience for Ukraine]. Visnyk Sums'koho derzhavnoho universytetu. seriya Ekonomika. Bulletin of Sumy State University. Economy Ser, 3, 61-67.

Pimonenko, T., Lyulyov, O., Chygryn, O., \& Palienko, M. (2018). Environmental Performance Index: Relation between Social and Economic Welfare of the Countries. Environmental Economics, 9(3), 1-11. doi:10.21511/ee.09(3).2018.01

Posey, C. (2015) Multiple Indicators and Multiple Causes (MIMIC) Models as a Mixed-Modelling Technique: A Tutorial and an Annotated Example. Communications of the Association for Information Systems, Vol. 36, Article 11. doi: 10.17705/1CAIS.03611.

Prokopenko, O., Chayen, S., Cebula, J., \& Pimonenko, T. (2017). Wind Energy in Israel, Poland and Ukraine: Features and Opportunities. International Journal of Ecology and Development, 32(1), 98107.

Prokopenko, O., \& Miśkiewicz, R. (2020). Perception of "Green Shipping" in the Contemporary Conditions. Entrepreneurship and Sustainability Issues, 8(2), 269-284. https://doi.org/10.9770/jesi.2020.8.2(16)

Saługa, P.W., Szczepańska-Woszczyna, K., Miśkiewicz, R., \& Chłąd, M. (2020). Cost of Equity of CoalFired Power Generation Projects in Poland: Its Importance for the Management of DecisionMaking Process. Energies, 13(18), 4833.https://doi.org/10.3390/en13184833

Savchenko, T., Basiurkina, N., Rodina, O., \& Kwilinski, A. (2019). Improvement of the Assessment Methods of Product Competitiveness of the Specialized Poultry Enterprises. Management Theory and Studies for Rural Business and Infrastructure Development, 41(1), 43-61. https://doi.org/10.15544/mts.2019.05

Schneider, F., \& Enste, D. (2000). Shadow Economies: Sizes, Causes and Consequences. Journal of Economic Perspectives, 38, 77-114. 
Schneider, F., Buehn, A., \& Montenegro, C. E. (2010). New Estimates for the Shadow Economies all over the World. International Economic Journal, 24(4), 443461. doi:10.1080/10168737.2010.525974

Tkachenko, V., Kwilinski, A., Korystin, O., Svyrydiuk, N., \& Tkachenko, I. (2019a). Assessment of Information Technologies Influence on Financial Security of Economy. Journal of Security and Sustainability, 8(3), 375-385. http://doi.org/10.9770/jssi.2019.8.3(7)

Tkachenko, V., Kwilinski, A., Klymchuk, M., \& Tkachenko, I. (2019b). The Economic-Mathematical Development of Buildings Construction Model Optimization on the Basis of Digital Economy. Management Systems in Production Engineering, 27(2), 119-123. http://doi.org/10.1515/mspe2019-0020

Tkachenko, V., Kwilinski, A., Tkachenko, I., \& Puzyrova, P. (2019c). Theoretical and Methodical Approaches to the Definition of Marketing Risks Management Concept at Industrial Enterprises. Marketing and Management of Innovations, 2, 228-238. http://doi.org/10.21272/mmi.2019.2-20

Tkachenko, V., Kwilinski, A., Kaminska, B., Tkachenko, I., \& Puzyrova, P. (2019d). Development and Effectiveness of Financial Potential Management of Enterprises in Modern Conditions. Financial and Credit Activity: Problems of Theory and Practice, 3(30), 85-94. https://doi.org/10.18371/fcaptp.v3i30.179513

Tkachenko, V., Kuzior, A., \& Kwilinski, A. (2019e). Introduction of Artificial Intelligence Tools into the Training Methods of Entrepreneurship Activities. Journal of Entrepreneurship Education, 22(6), 110.

World Bank. (2018a). World Development Indicators 2018. World Bank. Retrieved from https://data.worldbank.org/indicator.

World Bank. (2018b). Worldwide Governance Indicators. Retrieved from https://datacatalog.worldbank.org/dataset/worldwide-governance-indicators.

Wu, D., and Schneider, F. (2019). Nonlinearity Between the Shadow Economy and Level of Development. IMF Working Papers, 19/48, 1-29. Retrieved from https://www.imf.org/en/Publications/WP/Issues/2019/03/01/Nonlinearity-Between-theShadow-Economy-and-Level-of-Development-46618.

Yelnikova, Y., \& Miskiewicz, R. (2020). Implementation Mechanism of Impact Investing in the PostConflict Regions. Financial Markets. Institutions and Risks, 4(3), 53-65. https://doi.org/10.21272/fmir.4(3).53-62.2020

Yoo, T., \& Hyun, J. K. (1998). International Comparison of the Black Economy: Empirical Evidence Using Micro-Level Data, paper presented at 1998 Congress of Int. Institute Public Finance, Cordoba, Argentina.

Zellner, A. (1970). Estimation of Regression Relationships Containing Unobservable Independent Variables. International Economic Review, 11(3), 441-454. https://doi.org/10.2307/2525323 